University for Business and Technology in Kosovo

UBT Knowledge Center

UBT International Conference

2017 UBT International Conference

Oct 27th, 4:45 PM - 7:15 PM

\title{
Revitalization of new dinamo factory through the urban agriculture
}

Françeska Delia

Polytechnic University of Tirana, franceska.delia@yahoo.com

Ariana Neprvishta

Polytechnic University of Tirana

Follow this and additional works at: https://knowledgecenter.ubt-uni.net/conference

Part of the Architecture Commons

\section{Recommended Citation}

Delia, Françeska and Neprvishta, Ariana, "Revitalization of new dinamo factory through the urban agriculture" (2017). UBT International Conference. 3.

https://knowledgecenter.ubt-uni.net/conference/2017/all-events/3

This Event is brought to you for free and open access by the Publication and Journals at UBT Knowledge Center. It has been accepted for inclusion in UBT International Conference by an authorized administrator of UBT Knowledge Center. For more information, please contact knowledge.center@ubt-uni.net. 


\title{
REVITALIZATION OF NEW DINAMO FACTORY THROUGH THE URBAN AGRICULTURE
}

\author{
Françeska Delia ${ }^{1}$, Ariana Nepravishta ${ }^{2}$ \\ ${ }^{1}$ Faculty of Architecture and Urban Planning \\ Polytechnic University of Tirana, Albania \\ ${ }^{2}$ Faculty of Economic and Agribusiness \\ Agricultural University of Tirana, Albania \\ franceska.delia@yahoo.com
}

\begin{abstract}
Ever since ancient times the treatment of light and perception in the interior has been one of the main principles. It has always been a way of expressing, a language on the function and composition of a volume. This clearly states that the treatment of light in the interior is related to the typology, function and the psychological perception that we have about architecture. Nowadays in the time of modern architecture we have the opportunity to use light and volumetry in the interior in many different forms and complex textures. During a conceptual analysis done with a cube constantly changing the shape and position of the carved, we may notice that we have a change in the perception of space as well as a different psychological effect. The linear carvings located in the ceiling emphasize the main axis of the cubit creating an illusion of the extension of the building. If we had had carvings at the bottom of the cube, the idea of a disconnected space would have been created, which at the first expression seems to stay in the air, disconnected from the floor. This effect can give the idea of mystery in the interior, often used in religious buildings. Placement of small rhythmic carvings in the longitudinal section of the cube will create a rhythm by giving importance to only a certain axis. This is a good way of expressing the importance of an axis or a certain function through light. If we put small carvings like small holes, it will create the idea of a small sky in the interior with insufficient lighting. However, this will create peace of mind and can be used conceptually in exhibitions. The placement of the longitudinal carvings on the side walls will give the idea of framing the space and somehow will divide it. Natural interior light can be used as a form of communication, adapted to the function, volumetry and materials used in the interior.
\end{abstract}

Keywords: architecture, interior design, natural light, volume, perception of light

\section{Introduction}

\section{The historical background}

"Architecture is the skillful, accurate and magnificent plays of volumes seen in light." - Le Corbusier

Since ancient times, light has been an expressive form of architecture in the form of an expressive language. In ancient Egypt the temples used natural light as a form of orientation giving it and the greatest importance in designing. Its architecture and expressive language was closely linked with the cult and the faith in these places. This brought some kind of fanaticism and deep study of composition as well as the study of the motion of the sun and the orientation towards the building. 
"In Ancient Egyptian temples light was admitted to the Hypostyle Halls by clerestory, formed by the increased height of the columns in the central aisle, while the sanctuary was left dark or only dimly lit. Less prominent, but very common, lighting solutions included cutting angled slits or square holes into the roof slabs to allow daylight to enter the space "' (LaChiusa 2009). Egyptians were the first to make a detailed study not only in architecture but also in astrology. The discovery and derailment of the Sun Trajectory favored the positioning and space composition of the temples. By calculating the angle of the light, they achieved the perfect symmetry, making light the main element in the composition The light element was the one that oriented the composing in the interior by creating a central axis which counts exactly in the most important part of the temple. This was simultaneously related to their cult and belief in the sun and its power. "The most remarkable lighting scheme in Ancient Egyptian temples is the solar phenomenon at The Great Temple of Abu Simbel, where the axis of the temple was positioned in such a way that on October 21 and February 21 (allegedly the king's birthday and coronation day), the rays of the sun penetrate the sanctuary and illuminate the sculptures on the back wall, except for that of Ptah, the god of the Underworld, who should always remain in darkness. Due to the displacement of the temple and the accumulated drift of the Tropic of Cancer during 3,280 years, these two dates have moved one day closer to the Solstice, occurring now on October 22 and February 20" (Skliar 2005; Siliotti 2008)

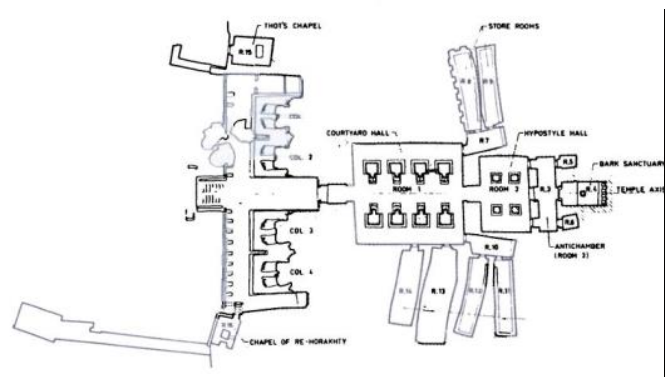

Fig.1 Planimetri e Abu Simbel, Egjipt

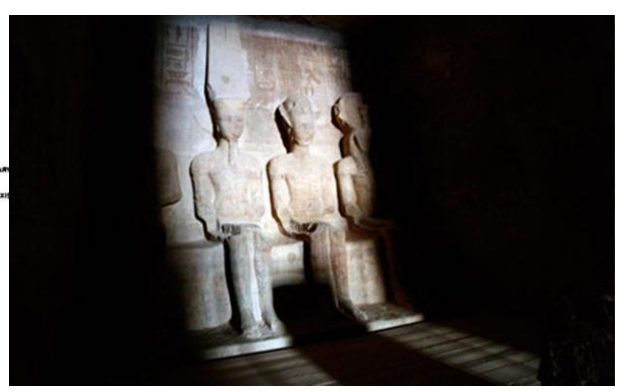

Fig.2 Interier I tempullit

Temples were occasionally 'hypaethral' or partly open to the sky, but this system appears to have been reserved for the larger temples such as the Olympieion, Athens. However, the most acceptable system is that of a row of windows over the internal colonnades (Fletcher 1905). In Roman architecture, natural light was a domain, to which Vitruvius devoted a whole chapter in his book 'De Architectura'. Roman space was concerned with lighting that allows interior decorations to be seen clearly. The oculus of the Pantheon is the most prominent treatment from this era, where light comes only from a round hole in the dome, about 9 meters in diameter, alluding to the (circular) perfection of the heaven and placing the emperor-god in direct relation with the heavens. 


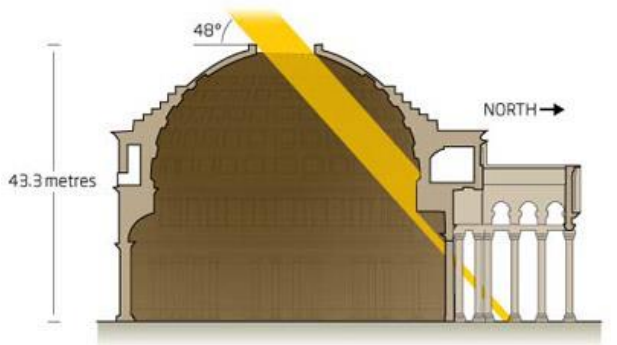

Fig.3 Prerje tre dimensionale e Panthenonit

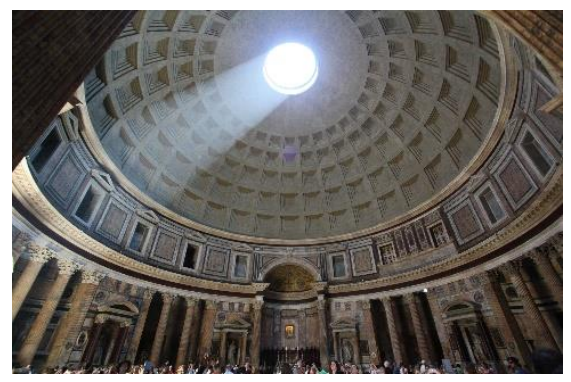

Fig.4 Interieri I Panthenonit

\section{A general review of the problem}

"Light is what gives character to architecture; without light form, color, or texture are not to be comprehended. It was considered as a celestial substance and the ultimate source of visual beauty in architecture since the earliest buildings. Depending on how it is used, light can transform the spatial context; create agreeable or disagreeable, sublime or mysterious sensations; or simply highlight aspects of the space that interest the viewer. Therefore, the history of architecture can be also told by referring to how natural light has been treated in accordance with different styles. Light has been used in the sacred buildings, not only to provide the necessary visual condition for the ritual acts to be performed, but also to evoke mystical and spiritual feelings. In ancient Egypt, where the sun was thought to be the eye of Ra, creator of the universe, temples were designed, so that, the sanctuary and processional paths were oriented according to its movement. In ancient Greek civilization temples were also orientated towards the east to relate directly to the first light of the day. The Romans, the first to consciously design interior space, also used light to enhance and articulate space and the most representative example for this concept was the Pantheon in Rome. Light was also given great significance in the early Judaism, Christianity and Islam. From the Byzantine monuments to the Gothic and Renaissance monuments, light was employed as the medium, through which the representation of heaven was given a temporal earthly reading" (Ramzy,2013)

Light in architecture and mainly on its impact on composing is a very discussed topic today, by many architects. From the period of modern architecture there were many different assumptions and experiments in the form, in the interior as well as in the materials that began to be used in architecture The treatment of light in the interior is an experimental process made from many archives over the years, which have been treated in various forms on the compositional side..

\section{Objectives}

The purpose of this research is to describe and analyze the influence of light on the perception of the interior, starting from the compositional and volume of the building. The pourpose of this research is to make a contribution to the conceptual analysis, perception and composition of the volume, starting with the best combination of these three. This will help in the process of volumetric creation of an architecture as well as the language that can be used in the interior.

\section{Research issues}

Questions that will help us in the sensory perception of light and the impact of volume in inertial are :

1. What is the story of light in architecture since antiquity?

2. What is the difference in volume in the perception of light in the interior? 


\section{Does the shape of light change based on the typology?}

\section{Theoretical background}

In the theory of light, it is common to find an explanation of what light is by considering it as energy or visible radiation. Our vision is then the perception determined by this radiation. However, the definition of our visual system by physiology and psychology goes to advanced image processing and psychological outcomes. When dealing with lighting analysis, many specialists consider light quality to be only physical aspects and run their principles by making measurements. They often rely their ideas based on a numeric and scaled light level, discussed in number of lux, which can be compared and detected by instruments. However, if we study deeper our relation to light, we will understand that light comprises a more complex field. Energy that can be measured it is not so reliable and comparative to our senses. According to Anders Liljefors's lighting fundamentals, physical and visual terms are running parallel. The combination between the physical and the visual worlds is served by the stimulus of vision, the optic radiation from 400 to $700 \mathrm{~nm}$ wavelength. The vision is primarily concerned with lighting quality, with the information that is received from the objects in the environment (Liljefors, 1999).

\section{Methodology}

The methodology will be based on two aspects:

1. Analyzing the history of architecture and the relationship of volume with light through literature.

2. Finding and analyzing different examples in typology from the point of view of composition and relationship of lights.

\section{Development}

\section{Case studies}

Light can give power in architecture that affects the interior space and atmosphere. There is an increasing amount of transparent buildings being constructed all over the world along with LED installations that enforce the impression that light eliminates all relevance of shadow. However, Louis Kahn, known as the master of light, designs architecture was shaped by light and shadow. Louis Kahn's archetypical forms relate back to Greek architecture, which he studied in the 1950s:"Greek architecture taught me that the column is where the light is not, and the space between is where the light is. It is a matter of no-light, light, no-light, light. A column and a column brings light between them. To make a column which grows out of the wall and which makes its own rhythm of no-light, light, no-light, light: that is the marvel of the artist."(Louis Kahn). However, light was also a very important central element in Louis Kahn's philosophy because he regarded it as a"giver of all presences": "All material in nature, the mountains and the streams and the air and we, are made of Light which has been spent, and this crumpled mass called material casts a shadow, and the shadow belongs to Light.”(Louis Kahn). For Kahn, light is the maker of material, and material's purpose is to cast a shadow. 


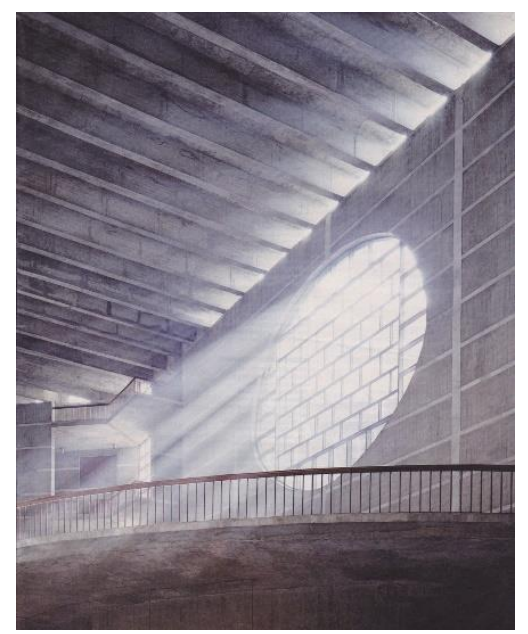

Fig.5 National Assembly in Dhaka, Bangladesh

And because Louis Kahn believed that the dark shadow is a natural part of light, Kahn never attempted a completely pure dark space for a formal effect. For Kahn, a glimpse of light elucidated the level of darkness:"A plan of a building should be read like a harmony of spaces in light. Even a space intended to be dark should have just enough light from some mysterious opening to tell us how dark it really is. Each space must be defined by its structure and the character of its natural light."(Louis Kahn) As a result, the light as a source is often hidden well behind louvres or secondary walls, thus concentrating all attention on the effect of the light and not simply on its origin.

"The "mysteriousness" of shadow was also closely linked to evoking silence and awe. For Kahn, while darkness evokes the uncertainty of not being able to see, of potential dangers, it also inspires deep mystery. It is in the hands of the architect to evoke silence, secret or drama with light and shadow - to create a "treasury of shadows," a "Sanctuary of Art." Even though Louis Kahn designed and constructed many buildings in regions exposed to extreme sunlight, he did not design his buildings just to protect users from the sun, but rather to protect the sanctity of the shadow. He did not believe in artificial shade. "The outside belongs to the sun and on the inside people live and work. In order to avoid protection from the sun I invented the idea of a deep intrados that protects the cool shadow."(Louis Kahn). Louis Kahn's path of designing with shadow has attracted and influenced numerous followers, like Tadao Ando with his Church of Light, Peter Zumthor and his Therme Vals or Axel Schultes with his Crematorium. All of these buildings include shadow as a form giver for silent spaces. This perspective presents a pleasant counterpoint in the modern architecture of today that strives for dynamic and bright icons.

\section{Conclusions}

This clearly states that the treatment of light in the interior is related to the typology, function and the psychological perception that we have about architecture. Nowadays in the time of modern architecture we have the opportunity to use light and volumetry in the interior in many different forms and complex textures.Natural interior light can be used as a form of communication, adapted to the function, volumetry and materials used in the interior. 


\section{References}

1. LaChiusa, C. (2009). Architecture around the World.

2. Fletcher, B. (1905). A History of Architecture on the Comparative Method for the Student, Craftsman, and Amateur. B. T. Agnew, \& CO., London, United Kingdom.

3. Skliar, A. (2005). Grosse Kulturen der Welt - Ägypten,. Prisma Gütersloh, Berlin, Germany

4. Siliotti, A. (2008). Egypt: Temples, Men and Gods. White Star Publishers, Rome, Italy.

5. Ramzy.N (2013). Perceptual Dimension of Interior Daylight in Sacred Architecture: Analytical Study of the Lighting Programs in Five Sacred Buildings of Different Styles, International Journal of Architecture, Engineering and Construction, El Arish City, Egypt

6. Liljefors, A (1999): Lighting - visually and physically. Lighting Department, Arkitekturskolan, KTH, Stockholm. 